\title{
Study on Solid Phase Extraction and Spectrophotometric Determination of Nickel in Waters and Biological Samples
}

\author{
Qiufen Hu, ${ }^{\dagger+*}$ Guangyu Yang, ${ }^{+\bullet}$ Zhangjie Huang, and Jiayuan Yin ${ }^{\dagger}$ \\ ${ }^{\dagger}$ Department of Chemistry, Kuman Universit, Kumming 650091, P.R. China \\ -Department of Chemistry, Yuxi Teachers College. Yuxi. 653100, P.R. China \\ Received April 25, 2003
}

\begin{abstract}
A sensitive. selective and rapid method for the determination of nickel based on the rapid reaction of nickel(II) with QADMAA and the solid phase extraction of the Ni(II)-QADMAA chelate with $\mathrm{C}_{18}$ membrane disks has been developed. In the presence of $\mathrm{pH} 6.0$ buffer solution and sodium dodecyl sulfonate (SDS) medium. QADMAA reacts with nickel to form a violet complex of a molar ratio of $1: 2$ (nickel to QADMAA). This chelate was enriched by solid phase extraction with $C_{18}$ membrane disks. An enrichment factor of 50 was obtained by elution of the chelates form the disks with the minimal amount of isopentyl alcohol. The molar absorptivity of the chelate was $1.32 \times 10^{5} \mathrm{~L} \mathrm{~mol}^{-1} \mathrm{~cm}^{-1}$ at $590 \mathrm{~nm}$ in the measured solution. Beer's law was obeyed in the range of $0.01-0.6 \mu \mathrm{g} / \mathrm{mL}$. This method was applied to the determination of nickel in water and biological samples with good results.
\end{abstract}

Key Words : 2-(2-Quinolylazo)-5-dimethylaminoaniline, Nickel, Spectrophotometry, Solid phase extraction

\section{Introduction}

Nickel is an important element. not only for industry. but for biological systems as well. 1.: Many' sensitive instrumental methods. such as spectrofluorimetry. X-ray fluorescence spectrometry. neutron activation analysis. atomic absorption spectrometry. chemiluminescence. have widely been applied to the determination of nickel. ${ }^{3-8}$ However the spectrophotometric method still has the advantages of simplicity and of not requiring expensive or complicated test equipment. This has led to the development of a wide variety of spectrophotometric methods for the determination of nickel. ${ }^{\$-16}$

In previous work, we reported some 2-quinoly lazo-phenol reagents for the determination of metal ions. ${ }^{16-i}$ This kind of reagent. because of its larger conjugated sy stem. has a higher sensitivity than pyridylazo reagents. However. the 2-quinolylazo-phenol reagent has also the disadvantage of its poor selectivity because both the oxygen atoms and nitrogen atoms donate to the metal ions. To select a more sensitive and selective reagent. we synthesized 2-(2-quinoliny lazo)-5dimethylaminoaniline (QADMAA) and thoroughly studied the color reaction of QADMAA with nickel. This reagent has higher selectivity than 2-quinolylazo-phenol reagents because it only donates nitrogen atoms to metal ions.

Routine spectrophotometric methods are often not sensitive enough to determine low concentrations of nickel ion in environmental samples. i.e. nickel concentrations less than the $\mu \mathrm{g} / \mathrm{L}$ level. Consequently. a preconcentration step is usually required. Solid phase extraction is an attractive teclunique because of its notable advantages. ${ }^{2-26}$ The present paper. based on the color reaction of QADMAA with nickel and the solid phase extraction of the colored chelate with $C_{18}$

\footnotetext{
Corresponding Author. Fax: +86-871-8316812; e-mail: huquufena â163.com
}

disks. describes the development of a highly sensitive. selective and rapid method for the determination of nickel in water and biological samples.

\section{Experimental Section}

Experimental Apparatus. A UV-160A spectrophotometer (Shimidzu. Japan) equipped with $1 \mathrm{~cm}$ microcells $(0.5$ $\mathrm{mL}$ ) was used for all absorbance measurements. The $\mathrm{pH}$ values were determined with a Beckman $\Phi-200 \mathrm{pH}$ meter. The extraction was performed on Waters Solid Phase Extraction (SPE) Device (It can prepare twenty samples simultaneously), and Zorbax $\mathrm{C}_{18}$ membrane disks [47 num (diameter) $\times 0.5 \mathrm{~mm}$ (thickness). $8 \mu \mathrm{m} .50 \mathrm{mg}$ ] (Agilent Teclunologies. USA) were used.

Reagents. Sinthesis of $O A D M A A$ : 2-aminoquinoline $(6.9$ g) was dissolved in $500 \mathrm{~mL}$ of anhy'drous ethanol. To which. sodamide $(2.0 \mathrm{~g})$ was added. and the mixture was refluxed in a boiling water bath for $5 \mathrm{~h}$. followed by the addition of isoamyl nitrite $(7.4 \mathrm{~mL})$. The solution was refluxed for 30 min in a boiling water bath. The solution was cooled and stored over night at under $0^{\circ} \mathrm{C}$. The diazo salt was obtained by filtering this solution with an isolation yield of $95 \%$. The diazo salt was dissolved in $200 \mathrm{~mL}$ anhydrous ethanol. followed by the addition of $m$-dimethylaminoaniline $(5.7 \mathrm{~g}$ : $0.042 \mathrm{~mol}$ ). The carbon dioxide was ventilated into the solution with stirring until the $\mathrm{pH}$ reached about 8.0 . The solution was let stand for two days. evaporating to dryness. The residue was re-crystallized with $30 \%$ ethanol. QADMAA was obtained with $36 \%$ yield. The structure of QADMAA was verified by elemental analysis. IR (Fig. 1). ${ }^{1} \mathrm{H}$ NMR (Fig. 2), and MS (Fig. 3). Elemental analysis: $\mathrm{C}_{17} \mathrm{H}_{17} \mathrm{~N}_{5}$ found (calculated) $\mathrm{C} 69.82(70.08) . \mathrm{N} 23.83$ (24.04). H 6.04 (5.88). All these data show that the QADMAA has the structure in Figure 4. 

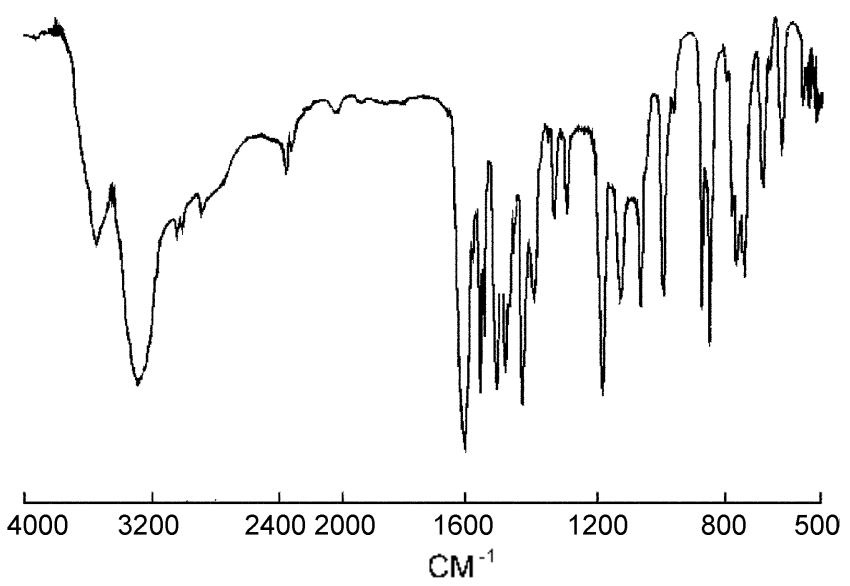

Figure 1. The inlrared spectrum ol QADMAA.

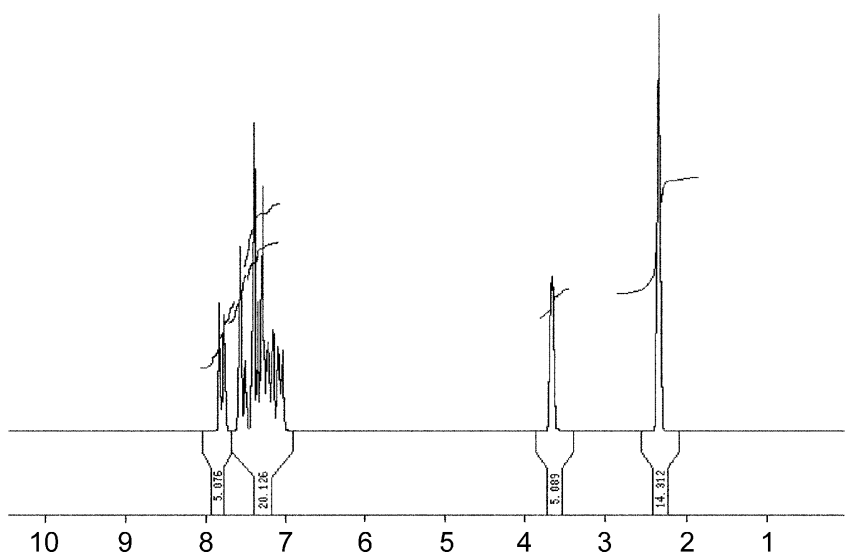

Figure 2. The $1 \mathrm{H}$ nuelcar magnetic resonance spectrum of QADMAA.

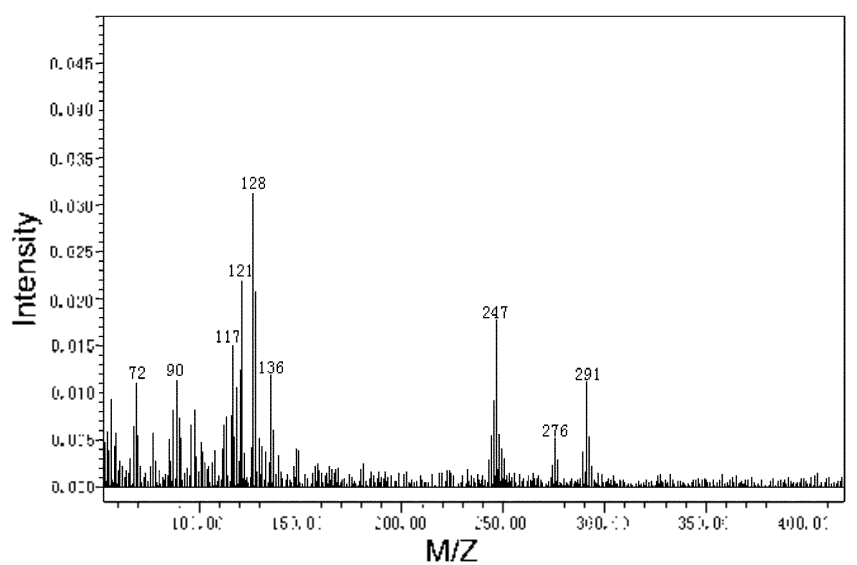

Figure 3. The mass spectrum of $(\mathrm{QD} \mathrm{D} M \wedge \wedge$.

All the solutions were prepared with ultra-pure water obtained from a Milli-Q50 SP Reagent Water System (Millipore Corporation, USA). High purity isopentyl alcohol (Fisher Corporation, USA) was used. A $5 \times 10^{-4} \mathrm{~mol} / \mathrm{L}$ of QADMAA solution was prepared by dissolving QADMAA with $95 \%$ of ethanol. A stock standard solution of nickel (1.0 $\mathrm{mg} / \mathrm{mL}$ ) was obtained from the Chinese Standard Center, and a work solution of $1.0 \mu \mathrm{g} / \mathrm{mL}$ was prepared by diluting<smiles>CN(C)c1ccc(N=Nc2ccc3ccccc3n2)c(N)c1</smiles>

Figure 4. The structure of QADMAA.

this solution. A hexamine-hydrochloric acid buffer solution, $0.5 \mathrm{~mol} / \mathrm{L}$, with a $\mathrm{pH}=6.0$ containing $0.1 \mathrm{~mol} / \mathrm{L}$, sodium thiosulfate and $0.2 \mathrm{~mol} / \mathrm{l}$, sodium fluoride), was used. Sodium dodecyl sulfonate (SDS) solution $(1.0 \%(\mathrm{~m} / \mathrm{v}))$ was prepared by dissolving SDS with water. All chemicals used were of analytical grade unless otherwise stated.

General procedure. To a standard or sample solution containing no more than $2.4 \mu \mathrm{g}$ of $\mathrm{Ni}(\mathrm{Il})$ in a $200 \mathrm{ml}$. calibrated flask, $10 \mathrm{~mL}$, of $0.5 \mathrm{~mol} / 1$. hexamine-hydrochloric acid buffer solution (containing $0.1 \mathrm{~mol} / \mathrm{L}$, sodium thiosulfate and $0.2 \mathrm{~mol} / \mathrm{L}$, sodium fluoride) with $\mathrm{pH} 6.0 .6 \mathrm{ml}$, of $5 \times$ $10^{-1} \mathrm{~mol} / 1$. QADMAA solution and $5.0 \mathrm{ml}$. of $1.0 \%$ SDS solution were added. The mixture was diluted to $200 \mathrm{ml}$. and mixed well. After $10 \mathrm{~min}$, the solution was passed through the $C_{18}$ disks at a flow rate of $50 \mathrm{~mL} / \mathrm{min}$. After the enrichment, the retained chelates were eluted from the disks with $4 \mathrm{ml}$, of isopentyl alcohol at a flow rate of $5 \mathrm{~mL} / \mathrm{min}$, and the eluent was adjusted to the accurate volume of 4.0 $\mathrm{mL}$, in a $4.0 \mathrm{ml}$, calibrated tlask by adding microamount of isopenty] alcohol with a $500 \mu \mathrm{L}$ syringes. The absorbance of the eluent was measured in a $1 \mathrm{~cm}$ cell at $590 \mathrm{~nm}$ against a reagent blank prepared in a similar way without nickel.

\section{Results and Discussion}

Absorption Spectra. The absorption spectra of QADMAA and its $\mathrm{Ni}(\mathrm{II})$ complex in isopentyl alcohol medium are shown in Figure 5. The absorption peaks of QADMAA and its complex are located at $454 \mathrm{~nm}$ and $590 \mathrm{~nm}$.

Effect of Acidity. Results show that the optimal $\mathrm{pH}$ for the

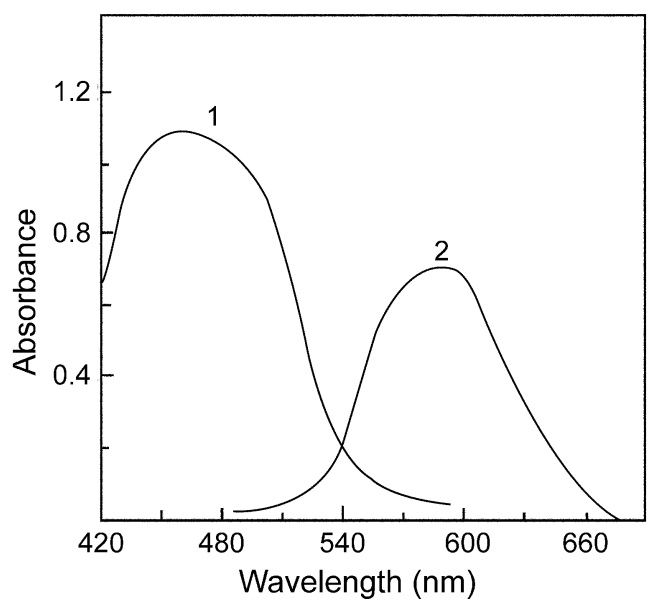

Figure 5. Absorption spectra of $\mathrm{Q} A \mathrm{I} M \mathrm{MA}$ and its Ni(II) complex in isopentyl alcohol medium: 1. Q $\triangle \mathrm{D} M \triangle A-\mathrm{SDS}$ blank against water: 2. QADMAA-Vi(II)-SDS complex against reagent blank. The concentration of $\mathrm{Vi}(\mathrm{Il})$ is $4.16 \times 10^{-6} \mathrm{~mol} / \mathrm{l}$. QADMAA is $3.22 \times 10^{-4}$ moll 1 . other conditions as general procedire. 


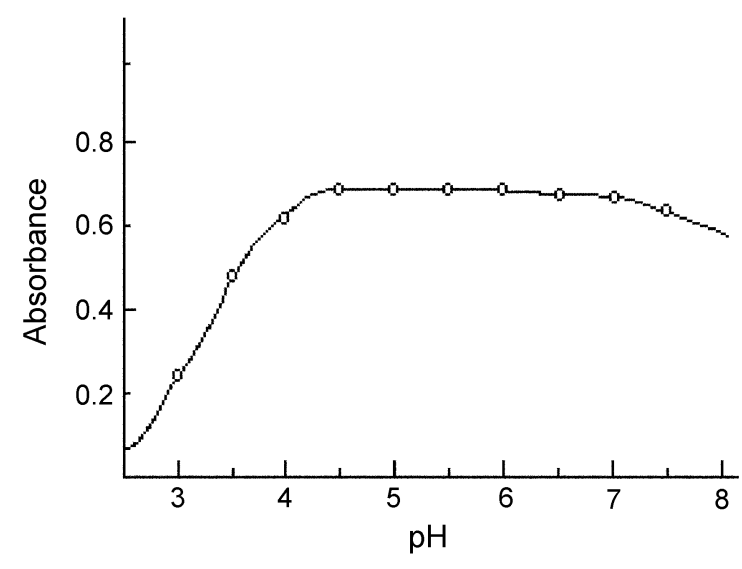

Figure 6. fiflect of pll on the formation of $\mathrm{Ni}(\mathrm{II})$ complex. Ni(II) concentration was $5.0 \times 10^{-6}$ mol..$^{-1}$. other conditions as general procedure.

reaction of Ni(II) with QADMAA is 4.8-8.2 (Fig. 6). An hexamine-hydrochloric acid buffer solution of $\mathrm{pH} 6.0$ is recommended to control $\mathrm{pH}$, as the use of 8-15 mL. buffer solution $(\mathrm{pH} 6.0)$ per $200 \mathrm{ml}$, of final solution was found to give a maximum and constant absorbance. The use of $10 \mathrm{~mL}$. of buffer solution is recommended. The buffer solution containing a $0.08-0.15 \mathrm{~mol} / \mathrm{l}$. of sodium thiosulfate and $0.15-0.25 \mathrm{~mol} / \mathrm{l}$, of sodium fluoride can increase the selectivity of this system [Without sodium thiosulfate and sodium fluoride in the buffer solution, the tolerance limits of foreign ions were $0.002 \mathrm{mg}$ for $\mathrm{Cu}(1 \mathrm{ll}), \mathrm{nn}(\mathrm{II}) ; 0.005 \mathrm{mg}$ for $\mathrm{Ag}(\mathrm{I})$. Fe(III). Pd (II). However, the tolerance limits of foreign ions reached $1.0 \mathrm{mg}$ for $\mathrm{Fe}(\mathrm{III}) ; 0.1 \mathrm{mg}$ for $\mathrm{Cu}(\mathrm{II})$, 7.n(II); $0.05 \mathrm{mg}$ for $\mathrm{Pd}(\mathrm{II})$. Ag(I) when sodium thiosulfate and sodium fluoride existed in the buffer solution]. So 0.1 $\mathrm{mol} / \mathrm{L}$ of sodium thiosulfate and $0.2 \mathrm{~mol} / \mathrm{L}$ of sodium fluoride in buffer are recommended.

Effect of Surfactants. The effect of surfactants on the Ni(II)-QADMAA chromogenic system is studied (Table 1). In the absence of surfactants, as well as cationic surfactants (cetyltrimethylammonium bromide (CTMAB)) or cetylpyridinium bromide (CPB)) medium, the Ni(II)-QADMAA chromogenic system gives a low absorption, whereas in the presence of anionic surfactants or nonionic surfactants medium, the absorption of the chromogenic system increases markedly. Experiments show that SDS is the best additive. The use 4-8 $\mathrm{mL}$ of SDS solution gives a constant and maximum absorbance. Accordingly, the use of $5 \mathrm{~mL}$ is recommended.

Effect of QADMAA Concentration, for up to $2.4 \mu \mathrm{g}$ of $\mathrm{Ni}(\mathrm{II})$, the use of about $5-10 \mathrm{~mL}$ of $5 \times 10^{-4} \mathrm{~mol} / \mathrm{L}$ QADMAA solution has been found to be sufficient for a complete reaction. Accordingly, $6 \mathrm{ml}$, of QADMAA solution were added in all further measurements.

Stability of the Chromogenic System. After mixing the components, the absorbance reached its maximum within 6 min at room temperature and remained stable for $6 \mathrm{~h}$ in aqueous solution. The chelates were stable at least $20 \mathrm{~h}$, after which they were extracted into the isopentyl alcohol medium.

Solid Phase Extraction. Both the enrichment and the elution were carried out on a Waters SPF. device (which can prepare twenty samples simultaneously). The flow rate was set to $50 \mathrm{ml} / \mathrm{min}$ for enrichment and $5 \mathrm{~mL} / \mathrm{min}$ for elution.

Some experiments were carried out to investigate the retention of QADMAA and its Ni(II) chelate on the disks. We found that the QADMAA and its $\mathrm{Ni}(I I)$ chelate can be retained on the disks quantitatively when they pass the disks as acpueous solution. The capacity of the disks for QADMAA was $36 \mathrm{mg}$ and for its $\mathrm{Ni}(I \mathrm{I})$-chelate $31 \mathrm{mg}$ in a $200 \mathrm{ml}$, of solution, In this experiment, the disks have adequate capacity to enrich the Ni(l)-QADMAA chelate and the excessive QADMAA.

In choosing the proper eluent to retained QADMAA and its $\mathrm{Ni}(11)$ chelate, various organic solvents were studied. The effect of various organic solvents was in the following sequence: isopentyl alcohol > acetonitrile > acetone > ethanol > methanol. So isopentyl alcohol was selected as the eluent. Our experiment shows that it is easier to elute the retained QAMAA and its $\mathrm{Ni}(11)$ chelate in reverse direction than in forward direction, so it is necessary to upturned the disks for the elution. $4.0 \mathrm{ml}$, of isopentyl alcohol was a sufficient amount to elute the QADMAA and its $\mathrm{Ni}(\mathrm{II})$ chelate from disks at a flow rate of $5 \mathrm{ml} / \mathrm{min}$. The volume of $4.0 \mathrm{~mL}$. eluent was selected.

Table 2. Iolarance limits for the determination of $2 \mu \mathrm{g}$ of Vi(II) with QADMAA (relative crror $\pm 5 \%$ )

\begin{tabular}{|c|c|}
\hline Ion added & $\begin{array}{l}\text { Tolerale } \\
\text { (mg) }\end{array}$ \\
\hline $\mathrm{NO}_{3}, \mathrm{~K}^{\prime}$, borale. $\mathrm{Mg}^{2}$ & 50 \\
\hline $1 . \mathrm{i}^{1}, \mathrm{Al}^{3+}, \mathrm{PO} \mathrm{1}^{3}, \mathrm{NO} \mathrm{O}_{2}, \mathrm{SO}_{4}{ }^{2}, \mathrm{ClO}_{4}$ & 5 \\
\hline $\mathrm{Ca}^{2}, \mathrm{Sr}^{2}, 10_{3}, 13 \mathrm{rO}, 13(\mathrm{III}), \mathrm{ClO}_{3}$ & 2 \\
\hline $\mathrm{Mn}^{2}, \mathrm{Ce}(\mathrm{IV}) \cdot \mathrm{I} \mathrm{e}^{3 \cdot}, \operatorname{Mo}(\mathrm{VI}) \mathrm{Br}$ & 1 \\
\hline lii(IV), $13 i(I I I), V(V), \operatorname{Cr}(V I), \operatorname{Cr}(V I), 13 a^{-}$W(WI), U(IV) & 0.3 \\
\hline$C d^{2}, P d^{21}, C r^{3-}, 1, d^{3}, C l, / n^{2}, C u^{21}, / r(I V)$ & 0.1 \\
\hline l3i(III), $\mathrm{Pb}^{21} \cdot \mathrm{H}_{\mathrm{g}}{ }^{2-}, \mathrm{Sb}^{3-}, \mathrm{Ih}(\mathrm{IV}), A \mathrm{~g}^{\prime} \cdot \operatorname{Sn}(\mathrm{IV}), \mathrm{P}_{\mathrm{d}^{21}}$ & 0.05 \\
\hline Se(IV). Te(IV). $A \mathrm{u}^{3-}$ & 0.03 \\
\hline$C 0^{2}$ & 0.02 \\
\hline
\end{tabular}

Table 1. The eflect of surfactands on Ni(II)-QNIDMAA chromogenic system

\begin{tabular}{cccccccccc}
\hline Surfactant & Absence & CTMAB & CPB & TritonX-100 & Tween-80 & Tween-20 & SDS & SDBS & SLS \\
\hline$h_{\text {thix }}(\mathrm{nm})$ & 580 & 580 & 580 & 590 & 585 & 580 & 590 & 588 & 590 \\
$\varepsilon\left(\times 10^{4}\right)$ & 7.94 & 6.86 & 7.21 & 9.47 & 9.36 & 8.23 & 13.2 & 10.6 & 11.2 \\
$1 . \mathrm{mol}^{-1} . \mathrm{cm}^{-1}$ & & & & & & & & & \\
\hline
\end{tabular}

SIDS (Sodium dodecyl sulfonate). SDBSS (Sodium dodecyl benzenesulfonate). SI.S (Sodium lauryl sultate) 
Table 3. Detemination of nickel in the certified standard biological samples

\begin{tabular}{|c|c|c|c|}
\hline Samples & Standard value $(\omega \mathrm{u} / \mathrm{g})$ & $\begin{array}{l}\text { By this method } \\
(\mu \mathrm{g} / \mathrm{g})\end{array}$ & $\begin{array}{l}\operatorname{RSD} \% \\
(11=5)\end{array}$ \\
\hline $\begin{array}{l}\text { Humant hair } \\
\text { (GBW07601) }\end{array}$ & $\begin{array}{l}\mathrm{As}(0.28), \mathrm{B}(1.3), \mathrm{Bi}(0.34), \mathrm{Ca}(2900), \mathrm{Cd}(0.11), \mathrm{Ce}(1.2), \mathrm{Co}(0.71), \mathrm{Cr}(0.37), \mathrm{Cu}(10.2), \\
\mathrm{Fe}(54), \mathrm{Hg}(0.36), \mathrm{Mg}(360), \mathrm{Mn}(6.3), \mathrm{Mo}(0.073), \mathrm{Ni}(0.83), \mathrm{Pb}(8.8)\end{array}$ & 0.846 & 2.8 \\
\hline $\begin{array}{l}\text { Tea Leaf } \\
\text { (GBW08505) }\end{array}$ & $\begin{array}{l}\mathrm{As}(0.191), \mathrm{Ba}(15.7), \mathrm{Ca}(2840), \mathrm{Cd}(0.032), \mathrm{Co}(0.2), \mathrm{Cr}(0.8), \mathrm{Cu}(16.2), \mathrm{Fe}(373), \mathrm{Hg}(0.004) \\
\mathrm{Mg}(2240), \mathrm{Mn}(766), \mathrm{Ni}(7.61), \mathrm{Pb}(1.06), \mathrm{Se}(0.041), \mathrm{Zn}(38.7)\end{array}$ & 7.59 & 2.4 \\
\hline
\end{tabular}

Table 4. Detemination of Nickel in the water sample

\begin{tabular}{lcccc}
\hline Samples & $\begin{array}{c}\text { Reference } \\
\text { method } \\
(\mu \mathrm{g} / \mathrm{L})\end{array}$ & $\begin{array}{c}\text { Found } \\
(\mu \mathrm{g} / \mathrm{L})\end{array}$ & $\begin{array}{c}\text { RSD\% } \\
(\mathrm{n}=5)\end{array}$ & $\begin{array}{c}\text { Recovery (\%) } \\
(\mathrm{n}=5) \\
\text { (Add 1.0 } 10 \mathrm{~g} \text { nickel) }\end{array}$ \\
\hline River water & 46.7 & 48.2 & 2.5 & 96 \\
Lake water & 22.8 & 23.2 & 2.4 & 104 \\
Tap water & 14.9 & 15.6 & 2.7 & 97 \\
\hline
\end{tabular}

Calibration Curve and Sensitivity. The calibration curve shows that Beer's law is obeyed in the concentration range of $0.01-0.6 \mu \mathrm{g} \mathrm{Ni}(\mathrm{II})$ per $\mathrm{mL}$. The linear regression equation obtained was: $A=2.326 C(\mu \mathrm{g} / \mathrm{mL})+0.0125 .(r=0.9994)$. The molar absorptivity was calculated to be $1.32 \times 10^{5} \mathrm{~L}$ $\mathrm{mol}^{-1} \mathrm{~cm}^{-1}$ at $590 \mathrm{~nm}$. The relative standard deviation at a concentration level of $0.2 \mu \mathrm{g} \mathrm{Ni}(\mathrm{II})$ per $\mathrm{mL}$ (1l repeat determination) was $1.29 \%$.

Composition of the Complex. The composition of the complex was deternined by continuous variation and molar ratio method. Both showed that the molar ratio of $\mathrm{Ni}$ (II) to QADMAA is $1: 2$.

Interference. The selectivity of the proposed method was investigated by the determination $2.0 \mu \mathrm{g} / 200 \mathrm{~mL}$ of $\mathrm{Ni}$ (II) in the presence of various ions within a relative error of $\pm 5 \%$. See Table 2

Application. The proposed method has been successfully applied to the determination of nickel in biological samples and water samples.

For biological samples. an accurately weighed $0.20 \mathrm{~g}$ sample was placed in the Teflon high-pressure microwave acid digestion bonb (Fei Yue Analytical Instrument Factory. Shanghai, China). $2.5 \mathrm{~mL}$ of concentrated nitric acid and 2.5 $\mathrm{mL}$ of $30 \%$ hydrogen peroxide were added. The bombs were sealed tightly and then positioned in the carousel of the microwave oven (Model WL 5001. 1000 W, Fei Yue Analytical Instrument Factory, Shanghai. China). The system was operated at full power for $6.0 \mathrm{~min}$. The digest was evaporated to near dryness. The residue was dissolved with $1 \%$ of hydrochloric acid. and the nickel contents were analyzed according to general procedures. The results are shown in Table 3.

For water samples, the samples were acidified with hydrochloric acid and filtered with a $0.45 \mu \mathrm{m}$ filter. The nickel contents were analyzed according to general procedure. The results are shown in Table 4 . together with the results of a recovery test. A standard method using ICP-MS has been used as a reference method. The results are also shown in Table 4 .
Acknowledgement. This project was supported by the Natural Science Foundation of Yunnan Province (0111143).

\section{References}

1. Denlhhaus. E. : Salnikow. K. Critical Reniew's in Oncology 2002. $42(1) .1040-8428$

2. Baldan. A. Joumal of Materials Science 2002. 37(11), 21712202 .

3. Ming, H.: Zhang, Y. L. Jomnal of Trace and Microprobe Techiques 2002. 20. 1-14.

4. Betzzo. Z:: Marcano. E.: Gomez. C.: Ruiz. F.: Salas. J.: Quintal. M.: Garaboto. A. Jownal of AOAC Intenational 2002. $85(4)$. 1060-3271

5. Sreenivasa, K.: Balaji. T.: Prasada. T. Siectrochinica Acta, Part $B$ Atontic Spectroscopy 2002.57B, $1333-1338$.

6. Zendelovska. D.: Pavlowska. G.: Cundeva. K.: Stafilov. T. Talanta 2001. $54.139-146$.

7. Natalija. I.: Ershova. V: IFanov. M. Fresenius' Jownal of Analyical Chentistry 2000. 367,210-211.

8. Hu. Q. F. Yang. G. Y. Yin. J. Y. Anatwical and Bioantalytical Chentistry 2003. $375,831-835$.

9. Fan. X. Z: Zhu. C. H.: Zhang. G. F. The Analust 1998. 123. 109 112 .

10. Hu. Q. F.: Yantg. G. Y.: Huang. Z. J.: Yin. J. Y. Analutical Sciences 2003. $19(10), 1158-1161$.

11. Ma. Q. L.: Su, M. H.; Wang. Z. H.: Nie. L. H.: Liang. S. C.: Ma. H. M. Anatitica Chimica Acta 2001. $+39,73-79$.

12. Lucia. H. S.: Avila. T. M. C.: Cunha. A. I. Spectroscopy Letters 1999.32. $257-271$.

13. Fan. X. Z.: Zhu. C. H. Mficrochemical Jownal 1998. 59. 284293.

14. Hu. Q. F.: Yang. G. Y.: Tang. D. Y.: Yin. J. Y. Fenxi Huaxu 2002. 30.699-701

15. Zhao. S. L.: Xia. X. Q.: Ma. H. R.: Xi. H. J. Talanta 1994. 11. $1353-1356$.

16. Ishizuki. T.: Tsuzuki. M.: Yuchi. A.: Ozawa. T.: Wada. H.: Nakagawa, G. Anahtica Chintica Acta 1993. 272. 161-167.

17. Hu. Q. F.: Yang. G. Y.: Yang. J. H. Y Yn, J. Y. Jom of Eniroment Honitoring 2002. $f(6), 956-959$.

18. Yang. G. Y.: Hu. Q. F.: Huang. Z. J.: Yin. J. Y. Analytical Sciences 2003. 19. 299-302.

19. Simgh. I.: Poonam. M. Talanta 1984. 31. 109-112.

20. Li. Z.: Yang. G. Y.: Wang, B. X.: Jiang. C. Q: Yin, J. Y. Jom of Chronatography 4 2002, 971, 243-248.

21. Yang. G. Y.: Hu, Q. F, Huang, Z. J.; YIn, J. Y. Andlyical and Bioanalytical Chemisty 2002. 374. 1325-1329.

22. Garg. B. S.: Sharma. R. K.: Bhojak. N.: Mittal. S. Mficrochem. J 1999. 61.94-102.

23. Pyrzynska. K; Trojanowicz. M. Cnitical Reviews in dinalytical Chentistry 1999. 29, 313-321

24. Hu. Q. F: Yang. G. Y.: Yin. J. Y. Talama 2002. 57, 751-756

25. Haddad. P. R.: Doble. P.: Macka. M. J. Chromatogr: A 1999. 856. $145-162$.

26. Yang. G. Y.: Zhan1g. C. M.: Fhu. Q.: Yin. J. Y. Jownal of Chronatographic Science 2003, H(4), 195-199. 